\title{
Diversification of energy production and consumption in European Union countries
}

ABSTRACT: The aim of the research is to assess and discuss the diversity of energy production and consumption in European Union countries. The time scope covers the years 2007 and 2016. The diversity of EU countries was examined using the cluster analysis. The following diagnostic features were adopted for the analysis: energy dependency rate (in \%), gross inland consumption of energy per 10,000 inhabitants (toe/10,000 inhabitants), primary production of energy (all products) per 10,000 inhabitants (toe/10,000 inhabitants), primary production of renewable energies per 10,000 inhabitants (toe/10,000 inhabitants), primary production of energy (without renewable energy) per 10,000 inhabitants (toe/10,000 inhabitants). Comparing the included indicators from 2016 to 2007 for all EU countries, an increase was recorded only for the primary production of renewable energies per 10,000 inhabitants,. Based on the cluster analysis, the examined countries were divided into six groups. According to the results of the research carried out, Northern and Eastern European countries are characterized by low energy dependence. However, according to the analysis carried out, this dependence is guaranteed based on various energy sources. The Scandinavian countries (Sweden, Finland) owe their high independence to the production of large amounts of energy from renewable sources. On the other hand, countries such as the Netherlands, Denmark, Estonia and the whole of Eastern Europe are based on primary energy sources such as: coal, oil and gas. Southern

$\triangle$ Corresponding Author: Dorota Agnieszka Janiszewska; e-mail: dorota.janiszewska@tu.koszalin.pl

1 Koszalin University of Technology, Poland; ORCID iD: 0000-0003-1119-9388: e-mail: dorota.janiszewska@ tu.koszalin.pl

2019. The Author(s). This is an open-access article distributed under the terms of the Creative Commons Attribution-ShareAlike International License (CC BY-SA 4.0, http://creativecommons.org/licenses/by-sa/4.0/), which permits use, distribution, and reproduction in any medium, provided that the Article is properly cited. 
Europe countries (Greece, Spain, Italy, Portugal, Cyprus, Malta) are characterized by high energy dependence, as evidenced by low rates in the area of energy production, both in total and renewable and non-renewable energy production.

KEYWORDS: renewable energy, non-renewable energy, energy production, energy consumption, European Union countries

\section{Introduction}

Modern civilization is not able to live without energy. The issue of energy security, its change from solid to clean fuels is addressed both in the scientific and practical dimensions. In terms of socio-economic practice, specific goals are set, as well as guidelines for the production and consumption of energy. One of the Global Sustainable Development Goals directly concerns energy - "ensure access to affordable, reliable sustainable and modern energy for all" (United Nations) In relation to these guidelines renewable energy sources are promoted in the European Union, which should have a positive impact on the environment as well as on the economy and society. The European Union countries accepted the $3 \times 20$ targets by 2020 (reduction of $\mathrm{CO}_{2}$ emissions, reduction of total primary energy consumption, increase of renewable energy sources share in energy consumption) (EC 2010; EC 2011).

Looking for common solutions, it seems to be important to combine countries into groups with similar energy conditions. Therefore the aim of the research is to assess and discuss the diversity of energy production and consumption in European Union countries.

\section{Literature review}

An unambiguous definition of energy is extremely difficult. Universally available encyclopedias define it as a physical quantity used to quantify different processes and types of impact. Energy itself is subject to the laws of conservation of energy, i.e. it cannot be produced nor consumed (Krawiec 2010). Energy can take various forms: chemical, electromagnetic, mechanical, nuclear, thermal and electrical (Krawiec 2012). The most important feature of energy is the fact that energy does not form or disappear, but only passes between physical systems. In the processes of energy transfer between these systems, work is usually performed, which is why energy is defined as the ability to do work (Niedziółka 2010). In the most general way, energy sources can be divided into conventional and unconventional. Conventional energies are most often identified with energy obtained from fossil sources, mainly: coal, oil and gas. On the other 
hand, unconventional energy is energy obtained from renewable sources, mainly: water, wind, geothermal, solar energy, biofuels: solid, liquid and gas (Jabłoński and Wnuk 2009).

Energy is essential for economic development. It can be compared to water or air in this respect. Its necessity caused that it is perceived as a strategic good (Cichy 2006). Energy is the engine of economic development of every country, there is a constant struggle for maintaining the energy independence of individual states or economic blocks. The most developed countries in the world owe their industrial and social progress mainly to electro-intensive industries and highly advanced education systems. Due to the great importance of energy for economic development, it should be recognized that at all costs the energy sectors will be further developed and that these sectors are attractive (Kupczyk et al. 2010).

On a global scale, energy consumption in 1995 was 30\% higher than in 1965, and its increase by 2025 will be, according to forecasts, at a galloping pace. The reasons for the accelerated growth in energy consumption are mainly: global increase in energy demand and supply, population growth in the world, extraordinary development of the middle income class and the intensifying greenhouse effect (Krawiec 2012). It should be emphasized that at the beginning, civilization functioned in accordance with nature, using mainly wood and other biomass for energy purposes. However, along with economic development, these raw materials proved to be insufficient and from the $19^{\text {th }}$ century, primary energy carriers, i.e. coal, oil and gas, were started to be used. (Timmons et al. 2014). Until now, the supply of petroleum products has kept up with the demand. However, at present the supply of current oilfield production is not keeping up with the demand and it is necessary to operate new, more and more expensive shafts (Jabłoński and Wnuk 2009). This makes it necessary to look for new solutions, such as the use of renewable energy. In addition, there has also been a need for a more sustainable economic development, i.e. using fossil fuel resources in a more rational way (Juściński 2010) and based on methods and tools that measure and compare human impact on the environment (Panwar et al. 2011). The increase in the share of renewable energy sources in the fuel and energy balance contributes to the improvement of the efficiency of using and saving energy resources, improving the environment by reducing pollution into the atmosphere and water, and reducing the amount of generated waste (Jabłoński and Wnuk 2009). In addition, the development of the renewable energy sector allows for the creation of new work places and supports the local economy using local labor, technologies and renewable resources (Nada and Alrikabi 2014).

The EU energy policy, its objectives and measures have been subject to a profound evolution under the influence of various factors, i.e. the global energy crises, ecological threats, the level of integration achieved, and the economic and political situation of member countries. As a result, its three main goals have been shaped: competitiveness of the economy, energy security of EU countries and protection of the natural environment against the harmful effects of the generation and delivery of energy (Pach-Gurgul 2012). 


\section{Research methods}

The analysis was based on Eurostat data (Eurostat 2017).The time range covers the year 2017. The European Union countries were divided into 8 clusters based on cluster analysis. The Euclidean metric was applied as a function of similarity. The following formula was used (Parysek and Wojtasiewicz 1979):

$$
d_{i k}=\sqrt{\sum_{j=1}^{m}\left(x_{i j}-x_{k j}\right)^{2}}
$$

where:

$d_{i k}-$ the distance between $i$-th and $k$-th object (for $i=k=1,2, \ldots, \mathrm{n}$ ),

$x_{i j}-$ value $j$-th variable for $i$-th object (for $j=1,2, \ldots, m$ ),

$x_{k j}-$ value $j$-th variable for $k$-th object.

The calculations were based on standardized variables. Moreover, the Ward method was applied in estimating the distance between clusters (Parysek and Wojtasiewicz 1979).

The analysis includes five diagnostic features: energy dependency rate (in \%), gross inland consumption of energy per 10,000 inhabitants (toe/10,000 inhabitants), primary production of energy (all products) per 10,000 inhabitants (toe/10,000 inhabitants), primary production of renewable energies per 10,000 inhabitants (toe/10,000 inhabitants), primary production of energy (without renewable energy) per 10,000 inhabitants (toe/10,000 inhabitants). The choice of indicators was based on the substantive and statistical criteria, as well as the availability of complete data.

\section{Results}

Over the last decade, the energy dependency rate in EU-28 has remained at a similar level, an average of 53.5\%. Taking individual energy sources into account, the largest dependence is in the total petroleum products range $-86.7 \%$ in 2016 ) and natural gas $-70.4 \%$. However, a smaller dependency exists in the area of solid fuels $-40.2 \%$ (in 2016) (Eurostat 2017), while the energy dependency rate in EU countries oscillated between $6.8 \%$ and $100 \%$. The average energy dependency rate in EU countries equaled 55.1\%. The lowest energy dependency rates occurred in: Estonia (6.8\%), Denmark (13.9\%), Romania (22.3\%), Poland (30.3\%) and Sweden (32.0\%). The highest energy dependency rates occurred in: Malta (100\%), Cyprus (96.2\%), Luxemburg (96.1\%), Italy (77.5\%) and Lithuania (77.4\%). Comparing the energy dependency rate of the EU 
countries from 2016 to 2007, favorable changes were noted. There was a decrease in energy dependency rate in 19 countries of the EU. The largest decrease occurred in Ireland (18.8 p.p.), Estonia (17.9 p.p.) and Latvia (15.3 p.p.). An increase in energy dependency rate occurred in the remaining 9 countries including: Denmark (37.9 p.p.), Lithuania (16.2 p.p.) and Czechia (7.7 p.p.). On average the energy dependency rate in 2016 compared to 2007 decreased by 1.6 p.p in the EU countries. The total energy consumption in EU-28 in 2016 was 1640.6 Mtoe. In the last decade, energy consumption has been dropping every year, by $1 \%$ on average. While comparing 2007 to 2016 , energy consumption dropped by $9 \%$. The largest energy consumption occurs in: Germany, France, United Kingdom and Italy. In total, these countries consume more than half (55.5\%) of the energy of the EU-28. Gross inland consumption of energy per 10,000 inhabitants in EU countries oscillated between 15.5 toe/10 thousand inhabitants and 72.9 toe/10 thousand inhabitants. The average value of this indicator equaled 33.6 toe/10 thousand inhabitants. The lowest gross inland consumptions of energy per 10,000 inhabitants occurred in: Malta (15.5 toe/10 thousand inhabitants), in Romania (16.4 toe/10 thousand inhabitants), Croatia (20.5 toe/10 thousand inhabitants), Latvia (22.3 toe/10 thousand inhabitants) and Greece (22.3 toe/10 thousand inhabitants). On the other hand, the highest gross inland consumption of energy per 10,000 inhabitants occurred in: Luxembourg (72.9 toe/10 thousand inhabitants), Finland (63.1 toe/10 thousand inhabitants), Belgium (50.8 toe/10 thousand inhabitants), Sweden (49.9 toe/10 thousand inhabitants) and Estonia (47.1 toe/10 thousand inhabitants). When comparing the gross inland consumption of energy per 10,000 inhabitants from 2016 to 2007, a decrease was noted in $25 \mathrm{EU}$ countries. The largest decrease occurred in: Luxembourg (24.4 p.p.), Malta (8.1 p.p.) and Cyprus (8.0 p.p.). An increase of gross inland consumption of energy per 10,000 inhabitants occurred in only three countries: Estonia (1.4 p.p.), Poland ( 0,9 p.p.), Latvia (0,2 p.p.). On average, the gross inland consumption of energy per 10,000 inhabitants in 2016 compare to 2007 decreased by 4.7 p.p. in the EU countries.

Total energy production in EU-28 in 2016 amounted to 755.4 Mtoe. In the last decade, energy production in EU fell by $1.4 \%$ on average. While comparing 2007 to 2016, energy production decreased by $12.3 \%$. The decline in energy production in EU-28 is the result of the increased import of energy and energy products. More than two thirds (68.2\%) of solid fuel import originated from three countries: Russia (30.2\%), Colombia (23.4\%) and Australia (14.6\%). More than half (52.6\%) of the crude oil comes from: Russia (31.9\%), Norway (12.4\%) and Iraq (8.3\%). While more than three quarters of the EU-28's imports of natural gas in 2016 come from: Russia (39.9\%), Norway (24.8\%) and Algeria (12.4\%). Such a situation may pose a threat to the EU-28's energy security, as a fairly large proportion of imports is concentrated among several suppliers. The primary production of energy (all products) per 10,000 inhabitants in EU countries fluctuated from 0.4 toe/10 thousand inhabitants to 35.5 toe/10 thousand inhabitants. The average value of this indicator was 14.8 toe/10 thousand inhabitants. The lowest primary production of energy per 10,000 inhabitants occurred in: Malta ( 0.4 toe/10 thousand inhabitants), Cyprus (1.5 toe/10 thousand inhabitants), Luxembourg ( 2.8 toe/10 thousand inhabitants). These countries are both small in area and have minimal amounts of their own energy resources, mainly from renewable sources. The highest primary production of energy per 10,000 inhabitants occurred in: 
Estonia (35.5 toe/10 thousand inhabitants), Sweden (35.1 toe/10 thousand inhabitants), Finland (32.0 toe/10 thousand inhabitants) The main energy resource of Estonia are bituminous shale and renewable sources. Finland and Sweden draw their energy mainly from nuclear and renewable sources. When comparing the primary production of energy (all products) per 10,000 inhabitants from 2016 to 2007 a decrease was noted in 12 EU countries. The largest decrease occurred in: Denmark (22.9 p.p.), the United Kingdom (10.4 p.p) and the Netherlands (9.6 p.p.). An increase occurred in the remaining 16 countries, the largest in: Ireland (5.7 p.p.), Latvia (4.4 p.p.), Estonia (2.7 p.p.) and Bulgaria (2.7 p.p). On average, the primary production of energy (all products) per 10,000 inhabitants in 2016 compared to 2007 decreased by 1.5 p.p in the EU countries.

Total renewable energy production in the EU-28 is 210.7 Mtoe, which is $27.8 \%$ of the total production. Energy production has been growing in the last decade. Comparing 2007 with 2016 , production increased by $54.6 \%$, while comparing year-on-year, it increased by an average of $5.0 \%$. The largest share in renewable energy production are solid biofules, hydropower and wind energy. The largest amount of renewable energy is produced by: Germany $(18.7 \%$ total production), France (11.3\%), Italy (11.3\%), Spain $(8.4 \%)$ and Sweden $(8.2 \%)$. The five countries mentioned produce almost $2 / 3(58.0 \%)$ of renewable energy produced in the EU-28. The primary production of renewable energies per 10,000 inhabitants in EU countries ranged from 0.4 toe/10 thousand inhabitants to 19.2 toe/10 thousand inhabitants. The average value of this indicator was 5.3 toe/10 thousand inhabitants. The lowest primary production of renewable energies per 10,000 inhabitants occurred on: Malta ( 0.4 toe/10 thousand inhabitants), Cyprus (1.5 toe/10 thousand inhabitants), Ireland (2.1 toe/10 thousand inhabitants), Luxembourg ( 2.2 toe/10 thousand inhabitants). Malta and Cyprus acquire renewable energy from solar, biomass and waste sources, while Luxembourg from biomass and waste. The main energy resource of renewable energy of Ireland is: wind, biomass and waste. The highest primary production of renewable energies per 10,000 inhabitants occurred in: Finland (19.2 toe/10 thousand inhabitants), Sweden (17.6 toe/10 thousand inhabitants), Latvia (12.4 toe/10 thousand inhabitants), Austria (11.2 toe/10 thousand inhabitants). Main renewable energy sources in those countries are: biomass, waste and hydro. Favorable changes were noted when comparing the primary production of renewable energies per 10,000 inhabitants of the EU countries from 2016 to 2007. An increase occurred in all countries, the largest in: Estonia (5.6 p.p) Latvia (4.3. p.p) and Finland (2.6 p.p). On average the primary production of renewable energies per 10,000 inhabitants in 2016 compared to 2007 decreased by 1.6 p.p. in the EU countries.

In total, 544.7 Mtoe are produced from non-renewable sources in the EU-28. The largest amount of energy excluding renewable sources is produced by: France (19.6\%), Germany (14.0\%), Poland $(10.5 \%)$ and the Netherlands $(7.6 \%)$. In total, the cited countries produce 281.6 Mtoe, or more than half (51.7\%) of the EU-28 energy. Over two-thirds (64.0\%) of this type of energy is derived from nuclear sources $(39.8 \%)$ as well as coal and lignite $(24.2 \%)$. The primary production of energy (without renewable energy) per 10,000 inhabitants oscillated from 0.0 toe/10 thousand inhabitants to 24.4 toe/10 thousand inhabitants. The average value of this indicator equaled 9.5 toe/10 thousand inhabitants. The lowest primary production of energy (without renewable energy) per 10,000 inhabitants occurred on: Malta ( 0.0 toe/10 thousand inhabitants), in 
TABLE 1. Selected indicators of energy production and consumption in EU member states in 2007 and 2016

TABELA 1. Wybrane wskaźniki w zakresie produkcji i konsumpcji energii w państwach UE w latach 2007 i 2016

\begin{tabular}{|c|c|c|c|c|c|c|c|c|c|c|}
\hline \multirow{3}{*}{ Countries } & \multicolumn{10}{|c|}{ Indicators } \\
\hline & \multicolumn{2}{|c|}{$\begin{array}{c}\text { energy } \\
\text { dependency rate } \\
\text { (in } \%)\end{array}$} & \multicolumn{2}{|c|}{$\begin{array}{c}\text { gross inland } \\
\text { consumption } \\
\text { of energy } \\
\text { per } 10,000 \\
\text { inhabitants } \\
\text { (toe/10,000 } \\
\text { inhabitants) }\end{array}$} & \multicolumn{2}{|c|}{$\begin{array}{c}\text { primary } \\
\text { production } \\
\text { of energy } \\
\text { (all products) } \\
\text { per } 10,000 \\
\text { inhabitants } \\
\text { (toe/10,000 } \\
\text { inhabitants) }\end{array}$} & \multicolumn{2}{|c|}{$\begin{array}{c}\text { primary } \\
\text { production } \\
\text { of renewable } \\
\text { energies } \\
\text { per } 10,000 \\
\text { inhabitants } \\
\text { (toe/10,000 } \\
\text { inhabitants) }\end{array}$} & \multicolumn{2}{|c|}{$\begin{array}{c}\text { primary } \\
\text { production of } \\
\text { energy (without } \\
\text { renewable } \\
\text { energy) } \\
\text { per } 10,000 \\
\text { inhabitants } \\
\text { (toe/10,000 } \\
\text { inhabitants) }\end{array}$} \\
\hline & 2007 & 2016 & 2007 & 2016 & 2007 & 2016 & 2007 & 2016 & 2007 & 2016 \\
\hline Belgium & 76.9 & 76.0 & 53.8 & 50.8 & 13.4 & 13.2 & 1.1 & 2.7 & 12.3 & 10.5 \\
\hline Bulgaria & 50.7 & 37.2 & 26.5 & 25.3 & 13.0 & 15.7 & 1.3 & 2.7 & 11.7 & 13.0 \\
\hline Czechia & 25.0 & 32.7 & 45.4 & 39.6 & 33.1 & 25.7 & 2.5 & 4.1 & 30.6 & 21.7 \\
\hline Denmark & -24.0 & 13.9 & 37.7 & 30.5 & 49.1 & 26.2 & 5.2 & 6.1 & 43.9 & 20.1 \\
\hline Germany & 58.5 & 63.5 & 40.6 & 38.6 & 16.6 & 14.1 & 2.8 & 4.8 & 13.7 & 9.3 \\
\hline Estonia & 24.7 & 6.8 & 45.8 & 47.1 & 32.8 & 35.5 & 5.5 & 11.1 & 27.3 & 24.4 \\
\hline Ireland & 87.9 & 69.1 & 36.6 & 31.3 & 3.2 & 8.9 & 1.1 & 2.1 & 2.2 & 6.8 \\
\hline Greece & 71.2 & 73.6 & 28.6 & 22.3 & 9.2 & 6.2 & 1.5 & 2.3 & 7.7 & 3.9 \\
\hline Spain & 79.6 & 71.9 & 32.7 & 26.3 & 6.7 & 7.3 & 2.2 & 3.8 & 4.5 & 3.5 \\
\hline France & 50.3 & 47.1 & 42.4 & 37.3 & 21.0 & 19.6 & 2.6 & 3.6 & 18.4 & 16.0 \\
\hline Croatia & 51.6 & 47.8 & 23.5 & 20.5 & 11.3 & 10.5 & 3.7 & 5.4 & 7.7 & 5.1 \\
\hline Italy & 83.0 & 77.5 & 32.3 & 25.5 & 5.4 & 5.6 & 2.7 & 3.9 & 2.6 & 1.6 \\
\hline Cyprus & 95.9 & 96.2 & 36.3 & 28.3 & 1.0 & 1.5 & 0.9 & 1.5 & 0.1 & 0.1 \\
\hline Latvia & 62.5 & 47.2 & 22.1 & 22.3 & 8.2 & 12.4 & 8.1 & 12.4 & 0.0 & 0.0 \\
\hline Lithuania & 61.2 & 77.4 & 28.6 & 24.2 & 11.4 & 5.6 & 3.0 & 5.2 & 8.5 & 0.4 \\
\hline Luxembourg & 96.7 & 96.1 & 97.3 & 72.9 & 2.5 & 2.8 & 1.8 & 2.2 & 0.7 & 0.6 \\
\hline Hungary & 60.0 & 55.6 & 27.2 & 26.1 & 10.6 & 11.6 & 1.8 & 3.2 & 8.8 & 8.3 \\
\hline Malta & 100.0 & 100.0 & 23.7 & 15.5 & 0.0 & 0.4 & 0.0 & 0.4 & 0.0 & 0.0 \\
\hline Netherlands & 37.7 & 45.8 & 50.9 & 46.2 & 36.8 & 27.1 & 1.4 & 2.8 & 35.4 & 24.4 \\
\hline Austria & 69.0 & 62.4 & 40.7 & 39.0 & 12.8 & 14.2 & 9.2 & 11.2 & 3.6 & 3.0 \\
\hline Poland & 25.5 & 30.3 & 25.4 & 26.3 & 18.8 & 17.5 & 1.3 & 2.4 & 17.5 & 15.1 \\
\hline Portugal & 81.4 & 73.5 & 24.9 & 22.5 & 4.4 & 5.8 & 4.3 & 5.6 & 0.1 & 0.2 \\
\hline Romania & 31.7 & 22.3 & 19.1 & 16.4 & 13.2 & 12.7 & 2.2 & 3.1 & 11.0 & 9.6 \\
\hline Slovenia & 52.5 & 48.4 & 36.5 & 32.9 & 17.2 & 17.3 & 3.6 & 5.4 & 13.5 & 11.9 \\
\hline Slovakia & 68.3 & 59.0 & 33.2 & 30.4 & 10.6 & 11.4 & 1.8 & 3.0 & 8.8 & 8.5 \\
\hline Finland & 52.9 & 45.3 & 70.7 & 63.1 & 30.4 & 32.0 & 16.6 & 19.2 & 13.8 & 12.8 \\
\hline Sweden & 35.8 & 32.0 & 54.3 & 49.9 & 36.1 & 35.1 & 16.5 & 17.6 & 19.6 & 17.4 \\
\hline United Kingdom & 20.5 & 35.3 & 36.4 & 29.0 & 28.7 & 18.3 & 0.7 & 1.9 & 28.0 & 16.4 \\
\hline Average & 56.7 & 55.1 & 38.3 & 33.6 & 16.3 & 14.8 & 3.8 & 5.3 & 12.6 & 9.5 \\
\hline
\end{tabular}

Source: own study based on EUROSTAT data. 
Latvia ( 0.0 toe/10 thousand inhabitants), Cyprus ( 0.1 toe/10 thousand inhabitants), Portugal ( 0.2 toe/10 thousand inhabitants) and Lithuania ( 0.4 toe/ 10 thousand inhabitants). Those countries do not possess non-renewable sources of energy or have them in minor quantities, which originate mainly from coal or crude oil. While the highest primary production of energy (without renewable energy) per 10,000 inhabitants occurred in: Estonia (24.4 toe/10 thousand inhabitants), Netherlands (24.4 toe/10 thousand inhabitants), Czechia (21.7 toe/10 thousand inhabitants), Denmark (20.1 toe/10 thousand inhabitants) and Sweden (17.4 toe/10 thousand inhabitants). In Estonia energy comes from bituminous shale. In Czechia energy comes from coal. The main energy source of Denmark is crude oil. The Netherlands acquire their energy from natural gas and Sweden from nuclear sources. When comparing the primary production of energy (without renewable energy) per 10,000 inhabitants from 2016 to 2007 a decrease was noted in $23 \mathrm{EU}$ countries. The largest decrease occurred in: Denmark (23.9 p.p), the United Kingdom (11.6 p.p) and the Netherlands (11.0 p.p). On average in the EU countries the primary production of energy (without renewable energy) per 10,000 inhabitants in 2016 compared to 2007 decreased by 3.1 p.p.

On the basis of selected indicators using the cluster analysis method, the analyzed countries were divided into six classes (Tab. 2, Fig. 1). The first group included seven countries, i.e.: Belgium, Germany, Ireland, Latvia, Hungary, Austria and Slovakia. The values of the analyzed indicators in this group are around the average for all the surveyed countries. The energy dependency rate is a little above average in these countries and equals $61.8 \%$ (with an average of $55.1 \%$ ). The gross inland consumption of energy per 10,000 inhabitants and the primary production of renewable energies per 10,000 people is also above-average for all countries in this group, accordingly 34.1 toe/10 thousand inhabitants (with the average of 33.6) and 5.6 toe/10 thousand inhabi-

TABLE 2. Diversification of energy production and consumption in EU member states researched features

TABELA 2. Zróżnicowanie produkcji i konsumpcji energii w pantwach UE - badane wskaźniki

\begin{tabular}{|l|c|c|c|c|c|c|c|}
\hline \multirow{2}{*}{\multicolumn{1}{|c|}{ Indicators }} & \multicolumn{5}{c|}{ Groups } & $\begin{array}{c}\text { Average } \\
\text { of indicators } \\
\text { for all countries }\end{array}$ \\
\cline { 2 - 9 } & I & II & III & IV & V & VI & 55.1 \\
\hline Energy dependency rate [in \%] & 61.8 & 38.3 & 81.4 & 96.1 & 24.8 & 38.7 & 33.6 \\
\hline $\begin{array}{l}\text { Gross inland consumption of energy per 10,000 } \\
\text { inhabitants [toe/10,000 inhabitants] }\end{array}$ & 34.1 & 26.8 & 23.5 & 72.9 & 40.9 & 56.5 & 14.8 \\
\hline $\begin{array}{l}\text { Primary production of energy (all products) per } \\
10,000 \text { inhabitants [toe/10,000 inhabitants] }\end{array}$ & 12.3 & 15.9 & 4.6 & 2.8 & 28.6 & 33.5 & 5.3 \\
\hline $\begin{array}{l}\text { Primary production of renewable energies per } \\
10,000 \text { inhabitants [toe/10,000 inhabitants] }\end{array}$ & 5.6 & 3.5 & 3.2 & 2.2 & 6.0 & 18.4 & 2.5 \\
\hline $\begin{array}{l}\text { Primary production of energy } \\
\text { (without renewable energy) per 10,000 inhabitants } \\
\text { [toe/10,000 inhabitants] }\end{array}$ & 6.6 & 12.4 & 1.4 & 0.6 & 22.6 & 15.1 & 9.5 \\
\hline Number of countries in class & 7 & 7 & 7 & 1 & 4 & 2 & 28 \\
\hline
\end{tabular}

Sources: own study. 


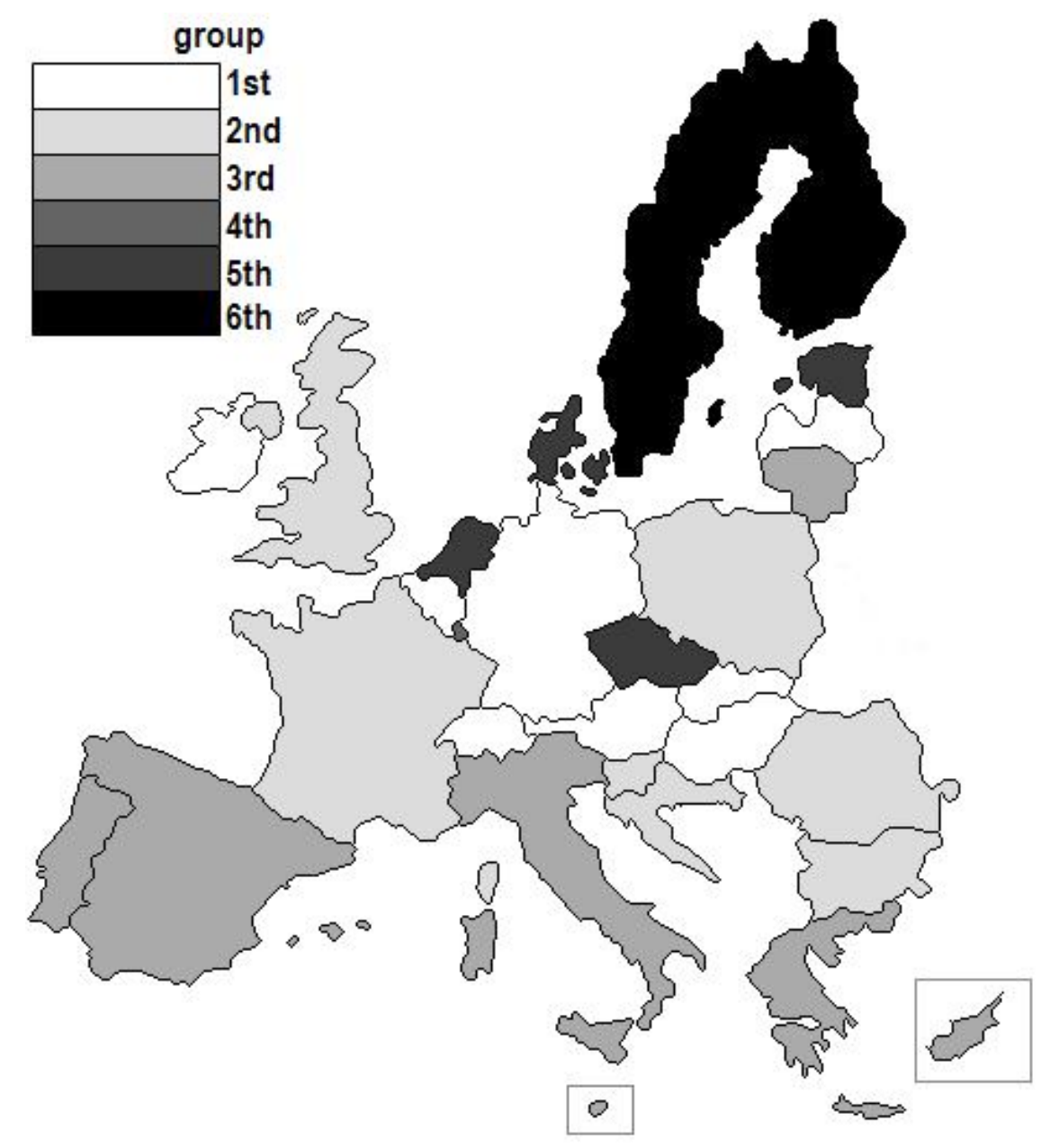

Fig. 1. Diversification of EU member states due to the production and consumption energy - typological groups Sources: own study

Rys. 1. Zróznicowanie państw UE ze względu na produkcję i konsumpcję energii - grupy typologiczne

tants (with the average of 5.3). The primary production of energy (all products) per 10,000 inhabitants and the primary production of energy (without renewable energy) per 10,000 inhabitants accordingly 12.3 toe/10 thousand inhabitants (with the average of 14.8) and 6.6 toe/10 thousand inhabitants (with the average of 9.5) is below-average.

The second group, like the first one, consists of seven countries, namely: Bulgaria, France, Croatia, Poland, Romania, Slovenia and United Kingdom. The characteristic feature of countries in this group is quite a low energy dependency rate as well as the gross inland consumption of energy per 10,000 inhabitants, which amounts to accordingly $38.3 \%$ and 26.8 toe/10 thousand 
inhabitants. In addition, countries in this group are characterized by quite a low primary production of renewable energies per 10,000 inhabitants ( 3.5 toe/10 thousand inhabitants) and an above-average primary production of energy (without renewable energy) per 10,000 inhabitants (12.4 toe/10 thousand inhabitants). These countries derive energy from various non-renewable sources, i.e.: coal (Poland, Bulgaria, Romania), nuclear (Slovenia, France), crude oil and natural gas (United Kingdom, Croatia, Romania). Renewable energy in these countries comes from biomass and waste.

The third group also included seven countries, namely: Greece, Spain, Italy, Cyprus, Lithuania, Malta and Portugal. A characteristic feature of these countries is quite a large energy dependency rate of around $81.4 \%$ and the lowest among all other groups gross inland consumption of energy per 10,000 inhabitants equaling 23.5 toe $/ 10$ thousand inhabitants. The primary production of energy (all products) per 10,000 inhabitants, the primary production of renewable energies per 10,000 inhabitants and the primary production of energy (without renewable energy) per 10,000 inhabitants in this group of countries is also much below the average, accordingly 4.6 toe/ 10 thousand inhabitants, 3.3 toe/ 10 thousand inhabitants, 1.4 toe/ 10 thousand inhabitants. The countries of this group have a minute energy production from renewable sources, mainly biomass and waste. The largest energy production in the countries of this group occurs in Spain (34.0 Mtoe, including $37.2 \%$ of production comes from renewable sources) and Italy (33.8 Mtoe including $70.5 \%$ from renewable sources).

The fourth group was formed by only one country, i.e. Luxembourg. A characteristic feature of this group is the highest energy dependency rate and gross inland consumption of energy per 10,000 inhabitants among other groups, the values of these indicators were respectively at the levels of $96.1 \%$ and 72.9 toe/10 thousand inhabitants. In addition, compared to other groups, the primary production of energy (all products) is the lowest per 10,000 inhabitants ( 2.8 toe/10 thousand inhabitants), the primary production of renewable energies per 10,000 inhabitants (2.2 toe/10 thousand inhabitants) and the primary production of energy (without renewable energy) per 10,000 inhabitants ( 0.6 toe/10 thousand inhabitants). Luxemburg is a country with a small area that does not have its own non-renewable sources of energy and it satisfies its energy needs by imports. Small quantities of renewable energy originate mainly from biomass and waste.

The fifth group was formed by only four countries: Czechia, Denmark, Estonia and the Netherlands. The countries of this group are characterized by the smallest energy dependency rate and the highest primary production of energy (without renewable energy) per 10,000 inhabitants, the values of the indicators are as follows: $24.8 \%$ and 22.6 toe/10 thousand inhabitants. Moreover, the countries of this group are also characterized by quite a high primary production of energy (all products) per 10,000 inhabitants (28.6 toe/10 thousand inhabitants) and the primary production of renewable energies per 10,000 inhabitants (6.0 toe/10 thousand inhabitants). Energy production in these countries is based on coal or bituminous shale (Czechia and Estonia), crude oil (Denmark) and natural gas (Netherlands). Renewable energy comes mainly from biomass and waste - Estonia $96.3 \%$, Czechia $90.3 \%$, Netherlands $80.0 \%$ and Denmark 65.1\%. 
The sixth and last group was formed by two countries: Finland and Sweden. The countries of this group have the highest primary production of energy (all products) per 10,000 inhabitants and the primary production of renewable energies per 10,000 inhabitants. The values of the indicators are as follows: 33.5 toe/10 thousand inhabitants and 18.4 toe/10 thousand inhabitants. In these countries, the gross inland consumption of energy per 10,000 inhabitants (56.5 toe/10 thousand inhabitants) and the primary production of energy (without renewable energy) per 10,000 inhabitants ( 15.1 toe/10 thousand inhabitants) is quite high. In addition, the countries of this group are characterized by quite a low energy dependency rate, equaling $38.7 \%$. Energy in those countries is produced mainly from nuclear and renewable sources. The largest share in renewable energy is derived from biomass, waste and hydro power.

\section{Discussion}

According to the conducted analyses, EU countries still largely consume primary energy sources which are limited and adversely affect the state of the environment. A sustainable approach to the energy sector is necessary if the world is to serve future generations. This is a challenge in relation to the energy transition - from dirty fuels to clean and efficient energy sources such as renewable energy sources (Krawiec 2010; Aceleanu et al. 2017; Akar 2016; Spaiser et al. 2017; Wu et al. 2017).

The significant difference between energy production and energy consumption needs and dependence on energy imports make the European Union vulnerable to the energy crisis. The European Commission policy in promoting renewable energy sources gives successful results. Investments in renewables reduce the necessity of import fossil fuels and energy, which contributes to the increase of energy security (Gökgöz and Güvercin 2018).

For increasing energy independences, not only renewable energy sources are needed but also the diversification of energy sources is promoted (EP 2017).

The energy security and independence is connected directly with national energy sources. Coal rich countries are characterized by quite high energy independences but this source of energy does not fit into the concept of sustainable development mainly due to $\mathrm{CO}_{2}$ emissions. According to the diversification of energy sources and energy transition, it is forecasted that the gas can overtake coal as well as renewable energy sources (AE\&S 2019).

It should be emphasized, however, that EU countries make many efforts to increase the share of energy from renewable sources, including many support measures, such as investment co-financing, tax exemptions (tax refunds) or various types of subsidies (Luty and Zioło 2016).

Although there are positive changes in the promotion of renewable energy sources in the European Union, these changes differ between countries. The energy mix depends, to a large extent, on domestic resources and the ability to produce primary energy. Therefore changes are taking place at a different pace in Northern Europe (higher share of RES) and a differently in 
coal rich countries (a smaller share of RES) (Fischer 2014; Ringel and Knodt 2018). In the field of the energy policy of the European Union, the Commission plans to further increase the share of renewable energy in energy consumption (EC 2014).

\section{Conclusion}

In accordance with the goal presented in the article, discussions and assessments of energy production and consumption in the European Union were made. The analysis of selected indicators shows that the countries of the European Union are diverse in terms of energy dependence, as well as production and energy consumption.

According to the results of the research carried out, Northern and Eastern European countries are characterized by low energy dependence. However, according to the analysis carried out, this dependence is guaranteed based on various energy sources. The Scandinavian countries (Sweden, Finland) owe their high independence to the production of large amounts of energy from renewable sources. On the other hand, countries such as the Netherlands, Denmark, Estonia and the whole of Eastern Europe are based on primary energy sources such as coal, oil and gas. Southern Europe countries (Greece, Spain, Italy, Portugal, Cyprus, Malta) are characterized by a high energy dependence, as evidenced by low rates in the area of energy production, both in total and renewable and non-renewable. However, it should be noted that these countries are characterized by the lowest energy consumption per capita.

Access to energy resources is crucial because it is the basis for the functioning of any economy. Ideally, the economy meets the energy needs based on its own resources, because it is not dependent on the grace or disfavor of other more resourceful countries. In the European Union countries, the production of energy from primary sources is decreasing from year to year, while the use of energy from renewable sources is increasing, however the energy dependency ratio is still quite high and amounts to over $50 \%$. The security of the EU's primary energy supplies may be threatened if a high proportion of imports are concentrated among relatively few partners, while there is no availability of alternative suppliers. Therefore, if it is not possible to increase the production of primary energy sources, appropriate steps should be taken to increase the production of energy from renewable sources, which will increase independence and will also have a positive impact on the natural environment.

\section{References}

AE\&S 2019. The European Power Sector in 2018. Up-to-date analysis on the electricity transition. Agora Energiewende and Sandbag, $44 \mathrm{pp}$.

EP 2017. EU Energy Independence, Security of Supply and Diversification of Sources. Brussels: European Parliament Policy Department A: Economic And Scientific Policy, 61 pp. 
Aceleanu et al. 2017 - Aceleanu, M.I. Serban, A.C. Pociovalisteanu, D.M. and Dimian, G.C. 2017. Renewable energy: A way for a sustainable development in Romania. Energy Source Part B 12 (11), pp. 958-963.

AKAR, B.G. 2016. The determinants of renewable energy consumption: An empirical analysis for The Balkans. European Scientific Journal 12 (11), pp. 594-607.

CicHY, P. 2006. Alternative energy sources (Alternatywne źródta energii). [In:] Kuciński, K. ed. Energy in the crisis times (Energia w czasach kryzysu). Warszawa: Difin, p. 147 (in Polish).

Eurostat 2017. Energy, transport and environment indicators. 2017 edition. Luxembourg: Publications Office of the European Union, p. 51.

EC 2010. Communication from the Commission to the European Parliament, the Council, the European Economic and Social Committee and the Committee of the Regions Energy 2020 A strategy for competitive, sustainable and secure energy (COM/2010/0639 final).

EC 2011. World and European Energy and Environment Transition Outlook. Studies and Reports. Brussels: European Commission, pp. 64-69.

EC 2014. Communication From The Commission To The European Parliament, The Council, The European Economic And Social Committee And The Committee Of The Regions. A policy framework for climate and energy in the period from 2020 to 2030. (COM/2014/015 final).

FISCHER, S. 2014. The EU's new energy and climate: policy framework for 2030. SWP Comments 55, pp. 1-8.

GÖKGÖZ, F. and GÜVERCIN, M.T. 2018. Energy security and renewable energy efficiency in EU. Renewable and Sustainable Energy Reviews 96, pp. 226-239.

JABŁOŃSKI, W. and WNUK, J. 2009. Management of renewable energy sources. Economic and technical aspects (Zarządzanie odnawialnymi źródłami energii. Aspekty ekonomiczno-techniczne). Sosonowiec: Humanitas Publishing House, p. 29 (in Polish).

JUŚCIŃSKI, J. 2010. Perspecttive for the development of renewable energy sources (RES) in Poland by 2020 (Perspektywy rozwoju odnawialnych źródel energii (OZE) w Polsce do 2020 roku). [In:] Krawiec, F. ed. Renewable energy sources in the light of the global energy crisis. Selected problems (Odnawialne źródła energii $w$ świetle globalnego kryzysu energetycznego. Wybrane problemy). Warszawa: Difin, p. 32 (in Polish).

KRAWIEC, F. 2010. The role of renewable energy sources in solving the global energy crisis (Rola odnawialnych źródel energii w rozwiazywaniu globalnego kryzysu energetycznego). [In:] Krawiec, F. ed. Renewable energy sources in the light of the global energy crisis. Selected problems (Odnawialne źródta energii w świetle globalnego kryzysu energetycznego. Wybrane problemy). Warszawa: Difin, p. 16 (in Polish).

KRAWIEC, F. 2012. Energy - resources, processes, technologies, markets, transformations, business models, development planning (Energia - zasoby, procesy, technologie, rynki, transformacje, modele biznesowe, planowanie rozwoju). Warszawa: Difin, pp. 40-41 (in Polish).

KUPCZYK et al. 2010 - KUPCZYK, A. WÓJCIK, A. and MAJKOWSKA, M. 2010. Selected problems of development of the agricultural biogas sector in Poland (Wybrane problemy rozwoju sektora biogazu rolniczego $w$ Polsce). [In:] Krawiec, F. ed. Renewable energy sources in the light of the global energy crisis. Selected problems (Odnawialne źródła energii w świetle globalnego kryzysu energetycznego. Wybrane problemy). Warszawa: Difin, pp. 80-81 (in Polish).

LUTY, L. and Zı૦ŁO, M. 2016. Importance of renewable energy sources in the Visegrad Group countries (Zróżnicowanie odnawialnych źródel energii w krajach Grupy Wyszehradzkiej). Quantitative Methods in Economics XVII (2), pp. 75-85 (in Polish).

NADA, Kh. and AlRIKABI, M.A. 2014. Renewable Energy Types. Journal of Clean Energy Technologies 2(1), pp. 61-64. 
NiEDZIÓŁKA, D. 2010. Energy market in Poland (Rynek energii w Polsce), Warszawa: Difin, p. 16 (in Polish).

PACH-Gurgul, A. 2012. The single electricity market in the European Union in the context of Poland's energy security (Jednolity rynek energii elektrycznej w Unii Europejskiej w kontekśsie bezpieczeństwa energetycznego Polski). Warszawa: Difin, p. 61 (in Polish).

PANWAR et al. 2011 - PANWAR, N.L. KAUShIK, S.C. and Kothari, S. 2011. Role of renewable energy sources in environmental production: A review. Renewable and Sustainable Energy Reviews 15, pp. 1513-1524.

PARYSEK, J. and WoJTASIEWICZ, L. 1979. Methods of regional analysis and methods of regional planning (Metody analizy regionalnej i metody planowania regionalnego). Warszawa: PWN, pp. 25-26 (in Polish).

TIMMONS et al. 2014 - TIMMONS, D. HARRIS, J.M. and ROACH, B. 2014. The economics of renewable Energy. Medford: Global Development And Environment Institute, Tufts University, p. 3.

RINGEL, M. and KNODT, M. 2018. The governance of the European Energy Union: efficiency, effectiveness and acceptance of the Winter Package 2016. Energy Policy 112, pp. 209-220.

SPAiSER et al. 2017 - SPAISER, V. RANGANATHAN, S. SwAIN, R.B. and SUMPTER, D.J.T. 2017. The sustainable development oxymoron: quantifying and modelling the incompatibility of sustainable development goals. International Journal of Sustainable Development \& World Ecology 24(6), p. 457-470.

United Nations. Sustainable Development Goals. [Online:] https://www.un.org/sustainabledevelopment/ energy/ [Accessed: 25.01.2019].

WU et al. 2017 - WU, G. LIU, D. and YAN, Y. 2017. Sustainable development and ecological protection associated with coal-fired power plants in China. International Journal of Sustainable Development \& World Ecology 24(5), p. 385-388.

\section{Zróżnicowanie produkcji oraz konsumpcji energii w państwach UE}

\section{Streszczenie}

Celem badań jest omówienie oraz ocena zróżnicowania produkcji i konsumpcji energii w państwach Unii Europejskiej. Zakres czasowy obejmuje rok 2007 i 2016. Zróżnicowanie państw UE zbadano za pomocą analizy skupień. Do analizy przyjęto następujące cechy diagnostyczne: współczynnik zależności energetycznej (w \%), krajowe zużycie energii brutto na 10 tys. mieszkańców (toe/10 tys. mieszkańców), produkcję energii (wszystkie źródła) na 10 tys. mieszkańców (toe/10 tys. mieszkańców), produkcję energii odnawialnej na 10 tys. mieszkańców (toe/10 tys. mieszkańców), produkcję energii nieodnawialnej na 10 tys. mieszkańców (toe/10 tys. mieszkańców). Porównując uwzględnione wskaźniki z 2016 do 2007 dla wszystkich państw UE, tylko w zakresie produkcji energii ze źródeł odnawialnych na 10 tys. mieszkańców odnotowano wzrost. W wyniku zastosowania analizy skupień podzielono badane państwa na sześć grup. 
Zgodnie z wynikami przeprowadzonych badań państwa Europy Północnej oraz Wschodniej charakteryzują się niską zależnością energetyczną. Jednak, jak wynika z przeprowadzonej analizy, zależność ta jest zagwarantowana w oparciu o różne źródła energii. Państwa skandynawskie (Szwecja, Finlandia) swoją wysoką niezależność zawdzięczają produkcji dużej ilości energii ze źródeł odnawialnych. Natomiast takie państwa jak Holandia, Dania, Estonia i cała część Europy wschodniej swoją niezależność opiera na pierwotnych źródłach energii takich jak węgiel, ropa naftowa czy gaz. Państwa Europy Południowej (Grecja, Hiszpania, Włochy, Portugalia, Cypr, Malta) natomiast cechują się dużą zależnością energetyczną, na co dowodem są niskie wskaźniki w zakresie produkcji energii, zarówno ogółem, jak i odnawialnej oraz nieodnawialnej.

SŁOWA KLUCZOWE: energia odnawialna, energia nieodnawialna, konsumpcja energii, produkcja energii państwa Unii Europejskiej 
